\title{
The Fall of Detroit: A Financial Economist's Point of View
}

\author{
Yu Peng Lin ${ }^{1}$ \\ ${ }^{1}$ Department of Economics, University of Detroit Mercy, Detroit, Michigan, USA \\ Correspondence: Yu Peng Lin, Department of Economics, University of Detroit Mercy, $4001 \mathrm{~W}$. McNichols \\ Road, Detroit, Michigan, 48221, USA. Tel: 1-586-263-6045. E-mail: linyp1@udmercy.edu
}

Received: April 15, 2014

Accepted: April 30, 2014

Online Published: June 25, 2014

doi:10.5539/ijef.v6n7p43

URL: http://dx.doi.org/10.5539/ijef.v6n7p43

\begin{abstract}
In this study, we offer a financial economist's view on the largest municipal bankruptcy in the U.S. history. While the city of Detroit's financial insolvency has been examined by researchers from various fields and several factors are considered attributable to the event, we believe the center of all issues is merely the city's lack of diversification strategy. This is evidenced by the deteriorating market share of the Big three, the dropping share of auto vehicles \& parts manufacturing employment in Detroit, and the city's long-term trend of declining population. While the auto industry did deliver Detroit a period of prosperity, this over-reliance on one industry inevitably brought financial difficulties on the city as the industry matures along with increased competitions.

This unfortunate outcome derived from a non-diversifying strategy is well predicted by the Portfolio theory. We believe with proper strategy of diversification, the city of Detroit could largely avoid its financial insolvency. The future of Detroit may well still cling to its determination to identify supporting industries and a well-developed economic plan.
\end{abstract}

Keywords: portfolio theory, diversification, urban development

\section{Introduction}

Detroit filed for bankruptcy protection on July 18, 2013 which makes it the largest municipal bankruptcy in the U.S. history by its debt level. However, this is barely shocking news given the economic standpoint of Detroit. According to the Michigan Governor Rick Snyder, there are one third of Detroit's residents live in poverty; about a fifth is unemployed; there are 78,000 abandoned buildings in Detroit.

There was a severe case of job sprawl within the metropolitan area of Detroit with jobs fleeing the urban core even when employment in greater Detroit was still rising. According to the Bureau of Labor Statistics, the Detroit metropolitan area is made up of two metropolitan divisions-Warren-Troy-Farmington Hills area and Detroit-Livonia-Dearborn area. Figure 1 shows the non-farm employment in the two divisions for the years from 1990 to 2013. Note that first, over the years, more than $50 \%$ of the employment is located in the Warren-Troy-Farmington Hills area. Second, there is a widening gap of employment in the two divisions suggesting a worsening employment condition in the Detroit-Livonia-Dearborn division since 1990. The 2013 Bureau of Labor Statistics report on the non-farm employment in the Detroit metropolitan area suggests that the Warren-Troy-Farmington Hills division accounted for more than 60 percent of the metropolitan area's total employment but over 75 percent of the area's job growth. Fewer than a quarter of the jobs on offer in the Detroit metropolitan area lie within 10 miles of the traditional central business district (i.e., Detroit-Livonia-Dearborn division). While comparing to Pittsburgh, the corresponding figure is higher than 50 percent (Krugman, 2013). This serious job sprawl has a number of causes as well as implications such as declining population, deteriorating housing value, and plummeting tax base. 


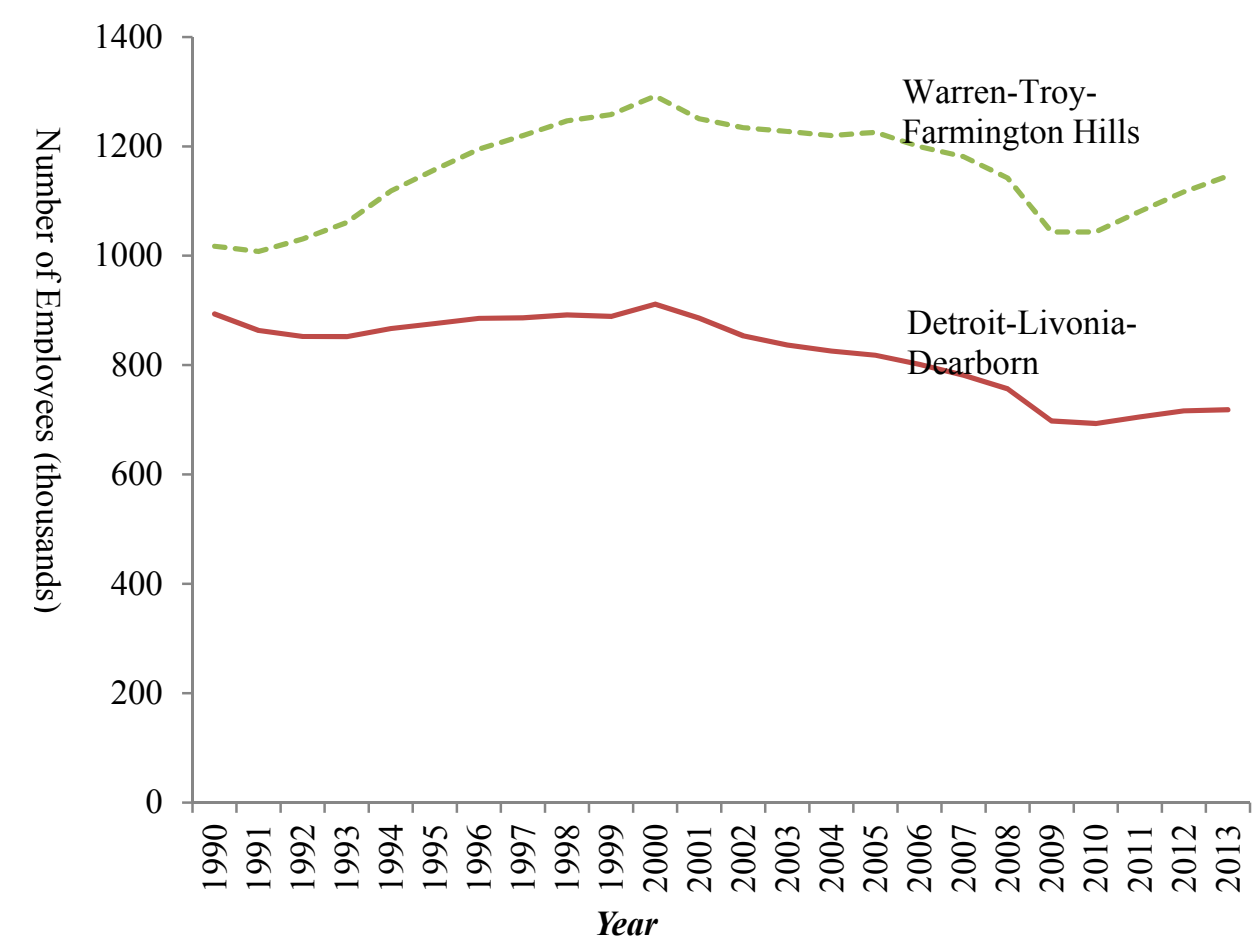

Figure 1. Non-farm employment in the Detroit area

Source: Bureau of Labor Statistics.

The factors that lead to Detroit's bankruptcy as well as the city's management dysfunctions have been explored by many scholars from various fields such as history, political science, and sociology. We do not plan to offer an extensive survey of those researches. Instead we try to examine the city's general economic conditions and how they lead to its financial insolvency from finance theories and practices.

While the pensions and related payments to city retirees (it is a 3.5 billion hole, after all) bear most of the blame, we believe the city of Detroit's financial insolvency in fact roots in a much broader set of factors. Yet we argue that these factors are merely the outcomes of the inability to diversify. In the current study, we attempt to understand the case of Detroit from the perspectives of city growth and the Portfolio theory in Finance. This study is organized as following: Section II provides a brief historical view of city formations, city growth, and an overview of the portfolio theory. We try to relate the concepts in section II to the city of Detroit's economic development in the past decades and discuss the roots of its failure in Section III. Section IV concludes.

\section{A Historical View of City Formation, Growth, and the Portfolio Theory}

\subsection{The Historical View}

According to Gordon (1978), the categories of economic structure are useful to divide up urban history. There are three time periods of urban development based on three stages through which the economy evolved: The commercial period (approximately 1620-1850); the industrial period (approximately 1860-1920); the corporate period (approximately 1920-present). During the commercial period, trading dominated cities and towns; in the industrial period, the process of manufacturing dominated; in the corporate period, mergers, stock sales, and the accumulation of paper wealth are the central activities (Kleniewski \& Thomas, 2006, p. 72).

Cities in the commercial period were quite small by today's standards and they all were ocean ports. This is largely attributable to the fact that trading was the major economic activities during this period. As the economy moved from commerce to increased manufacturing, the center of activity moved away from the port to a new center. The size and scale of cities grew tremendously. It is this period that social patterns became differentiates. Consider, for instance, there were different neighborhoods for people of different social classes. While continuing to the twentieth century, the urban economy was once more transformed. Although manufacturing is still important, the production of paper profits gained more attention. This trend was more pronounced as moving into the twenty-first century. Firms have become conglomerates producing a wide range of goods and services. One important characteristic of the corporate cities as suggested by Kleniewski and Thomas (2006) is 
the decentralization of economic activities. The trend toward differentiation of neighborhoods by social class continued in the corporate city as well. Due to the economic activity decentralization, urban areas have grown tremendously on the periphery. Along with more accomplished infrastructures, particularly transportation-related projects such as highways, more suburban housing were demanded and hence constructed which constitute the trend of wealthier residents moving farther from the center.

Among the factors that affect the growth and hence the changes of cities, in this research, we focus most of our attentions on corporations since their decisions as of where to locate, increase, or decrease their operations affect not only their own welfare but also impact hundreds and sometimes thousands of employees who work for them ${ }^{l}$. One corporation's decisions are highly related to its suppliers and competitors, which in turn involve even more workers. This impact of corporations is further reinforced by the clustering pattern of similar businesses, namely agglomeration. For example, automakers and their suppliers tend to locate in Detroit; Computer engineering in California's Silicon Valley. When industries cluster, they create urban areas with dominant firms and distinct economies. According to Markusen (1987), an understanding of the profit cycles of industries can help to explain why industries locate where they do and why companies agglomerate with similar ones. It can in turn help to understand the dynamics of cities and their economic development. Agglomeration can produce an economic boom in an area that becomes the site of an emerging industry since they create many jobs and spur population growth in that area. However, as the industry matures, the cities become more vulnerable to the corporations' business operations and decisions. On the other hand, while the businesses become unprofitable, the areas/cities they locate would experience the contraction as well. As a result, how to reduce or even avoid the unfavorable impact of maturing industries becomes a critical topic in the management of a city.

\subsection{Portfolio Theory and Rebalancing}

Nonetheless, not all cities with maturing industries or transforming from industrial to corporation experienced the same fate. For instance, New York City, Denver, and San Francisco became prominent service-sector cities and took on new economic functions in the global or regional economy while New Haven and Detroit failed to develop a large enough service sector to retain jobs in the central city (Fainstein \& Fainstein, 1983). Therefore, while the economy evolved through the three periods, the major factor we believe that determines the growing perspectives of a city would be its diversification strategy.

The concept of diversification was first introduced in the Portfolio Theory. Portfolio Theory generally describes a strategy that attempts to maximize portfolio expected return for a given amount of portfolio risk, or equivalently minimize risk for a given level of expected return, by carefully choosing the proportions of various assets. The theory was introduced by Harry Markowitz in 1952 and it eventually earned him a Nobel Prize in Economic Sciences in 1990. The fundamental concept behind the portfolio theory is that the assets in an investment portfolio should not be selected individually, each on its own merits. Rather, it is important to consider how each asset changes in price relative to how every other asset in the portfolio changes in price. Therefore, Portfolio theory is in fact a form of diversification. Under certain assumptions and for specific quantitative definitions of risk and return, the theory explains how to find the best possible diversification strategy to achieve the optimum combination of expected return and risk level.

There is a tradeoff between risk and expected return. In Finance, while applying the Portfolio Theory, investors try to achieve the highest possible expected return for a given amount of risk or to minimize the level of risk for a given expected return. Hence, by the theory, the tangency portfolio would be most efficient. Any portfolios contained inside the efficient frontier would be considered non-efficient in the sense that for its risk level, higher return is achievable or its risk can be reduced given the expected return.

Moreover, as time goes on, a portfolio's current asset allocation will drift away from an investor's original target asset allocation (e.g., their preferred level of risk exposure). If left unadjusted, the portfolio will either become too risky, or too conservative; hence, non-efficient in the language of the Theory. It is best to maintain a portfolio's risk profile reasonably close to an investor's level of risk tolerance. A common strategy to adjust the portfolio is rebalancing, which for instance, over-weighted investments can be sold to purchase under-weighted ones. The goal of rebalancing is to move the current asset allocation back in line to the originally planned asset allocation; hence bring it back to the tangency portfolio. Although the later developments of the Portfolio Theory mostly find their way to the fields of personal financial planning and portfolio management, we believe the concepts of diversification along with rebalancing can be equally useful in the economic planning of a city.

The set of industries located in a city reflects the city's industry "investment portfolio" given the fact that residents would be relying on those industries for jobs and hence, they are the sources of various tax revenues for the city. As is well known, industries or firms have their own life cycle. In the growing phase, tremendous job 
opportunities are offered. People would be attracted to the city and the city in turn would have a healthy tax base. Yet, while the businesses cluster (i.e., agglomeration), the industry's impact of the city becomes so significant that it represents an overweight in the city's "industry investment portfolio". At this point, the city will need to consider "rebalancing" its industry mix in an attempt to sustain the job growth and tax revenue stream since as the industry mature, the rate of new jobs creation would slow down, stabilize, or even decline. This could further be compounded by increased competition from other areas. The aforementioned examples of New York City, Denver, and San Francisco are instances of successful rebalancing while New Haven and Detroit belongs to the other side of the story.

\section{The Case of Detroit}

Although the city of Detroit was founded on July 24, 1701, it experienced its growth beginning in early 1900s due to the birth of the auto industry. Hence, while referring to the three periods of urban evolving history, Detroit had little in the way of a commercial heritage to overcome and grew up as a purer example of an industrial-type city. The Detroit area emerged as a significant metropolitan region within the United States as the construction of a regional freeway system was completed in the 1950s and 1960s.

Although there are various factors that could be accounted for the city's bankruptcy, Detroit's failure to diversify its economy is the major reason, we believe, that the city finds itself in dire straits. Unlike Pittsburg and Cleveland, the two former manufacturing powerhouses that turned around their finances by catering to growing industries such as health care, Detroit still clings to its past with heavy reliance on the auto industry and America's driving culture. The reliance on the auto industry indeed brought Detroit a period of prosperity. In the first half of the twentieth century, auto makers grew rapidly and invested in plants in and around Detroit as area residents became increasingly dependent on the auto industry for jobs. Likewise, the city of Detroit became increasingly dependent on the auto industry for tax revenues. Therefore, in the language of the Portfolio theory, Detroit had an "industry portfolio" which is somewhat risky but with good expected return over this period. However, as the auto-related businesses clustered in the Detroit area and the city failed to recognize the need to rebalance, this over-reliance back-fired the city's finance and economy. Since the 1960s, the market share of the Big Three started to decline due to increasing competition. Figure 2 shows the market share of the Big Three versus their international competitors. The share of the Big Three reached its peak in the early 1960s and then followed by a long period of declining. In the mid of 2000 s, their market share dropped, for the first time, below $50 \%$ and remains largely at that level afterwards (Note 2).

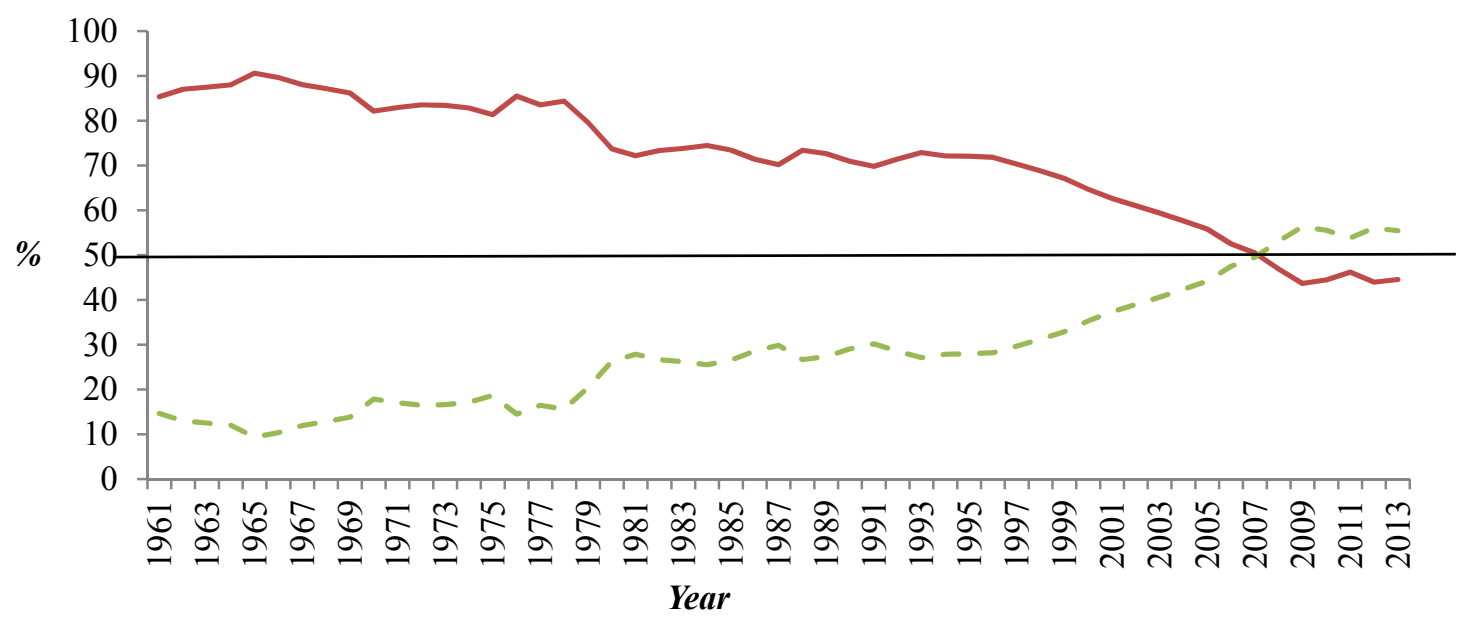

Figure 2. U.S. vehicle sales market share from 1961 to 2011

Figure 3 illustrates the weight of manufacturing employment as of total non-farm employments from 1956 to 2013 in the Detroit area. The weight dropped from $45 \%$ to a level below $15 \%$ over six decades, averaging to a $5 \%$ decline in each decade (Note 3). 


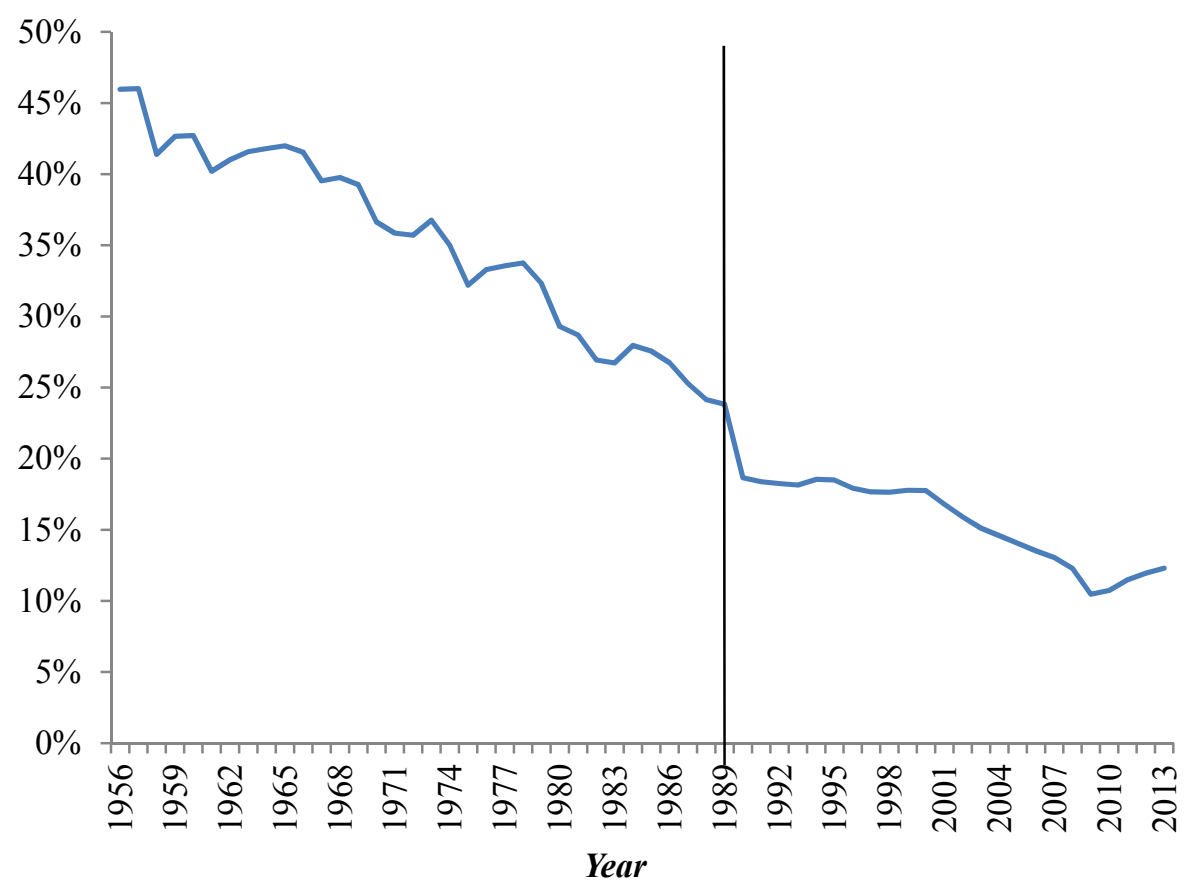

Figure 3. Weight of manufacturing employment on total-non-farm

Source: Bureau of Labor Statistics.

\begin{abstract}
Although there is no data relating the number of auto-related job losses per market share percentage drop in the automakers, according to McAlinden and Chen (2012), the ratio of automotive supplier employment to automaker employment is about three to one. Given this ratio, any market share drop would translate to a very pronounced decline in the total automobile-related job opportunities. Particularly beginning with the 1980s when foreign companies further challenged the dominance of the U.S. automakers, U.S. companies can no longer reap the profits they had become used to because of this increased competition. Besides dropping down their production scales in response to the declining market share, the other response by the automakers was to cut expenses by moving some of their manufacturing facilities from Detroit to other areas such as Tennessee to take advantage of lower labor cost, beginning the gradual decrease in automotive-related jobs in Detroit. This is further compounded by two other factors. First, the changes in the world economy such as the dramatic increases in oil prices and world-wide recession. Second, the gradual increases in the level of automation in manufacturing plants during the past decades. Figure 4 shows the motor vehicles \& Parts Manufacturing employment in the Detroit metropolitan area as well as in the two metropolitan divisions from 1990 to 2013 (Note 4). The slight increase in the 1990s is largely the outcome of the relatively flat market share of the Big Three in the same period. However, the decline in market share in the 2000s inevitably dragged the automobile-related employment along with it.
\end{abstract}




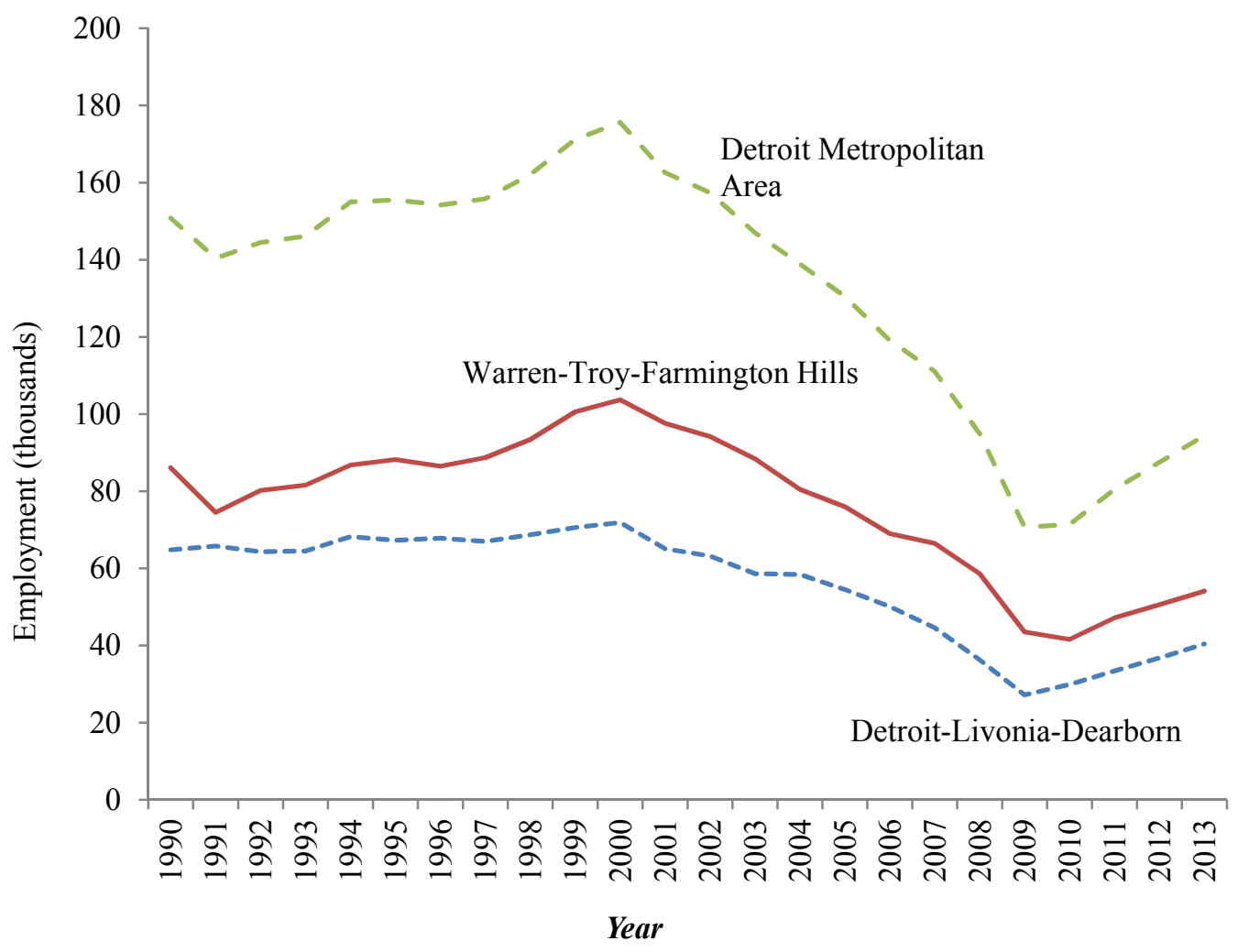

Figure 4. Motor vehicles \& parts manufacturing employment

Source: Bureau of Labor Statistics.

With the dropping of production scales, the re-location of production facilities, and the increased rate of automation, there was much less automotive-related jobs available. These changes presented several serious challenges to the city of Detroit. The dispersion of manufacturing decreased the demand for manufacturing workers. Hence, the equilibrium total employment decreased, causing population losses (O'Sulliean, 2012). This trend of job disappearance and hence population losses are further intensified by the lack of industry diversification and rebalancing strategies from the city government. As a result, there were very limited jobs available in other industries to compensate for the decline of positions in the automotive-related sectors. People started moving out.

Detroit experienced a very significant population decline from 1950 while there was close to 2 million residents to about 700,000 in 2010 as shown in Figure 5. It is an astonishing 61\% drop in population over only six decades. There was two decades-1970s and 2000s when Detroit experienced more than $20 \%$ decline. While combining figures $1 \sim 5$, one can observe a clear path as well as the consequences of the over-reliance on the auto industry of Detroit. This population outflow has an obvious yet unfavorable implication on the property values in the city. 


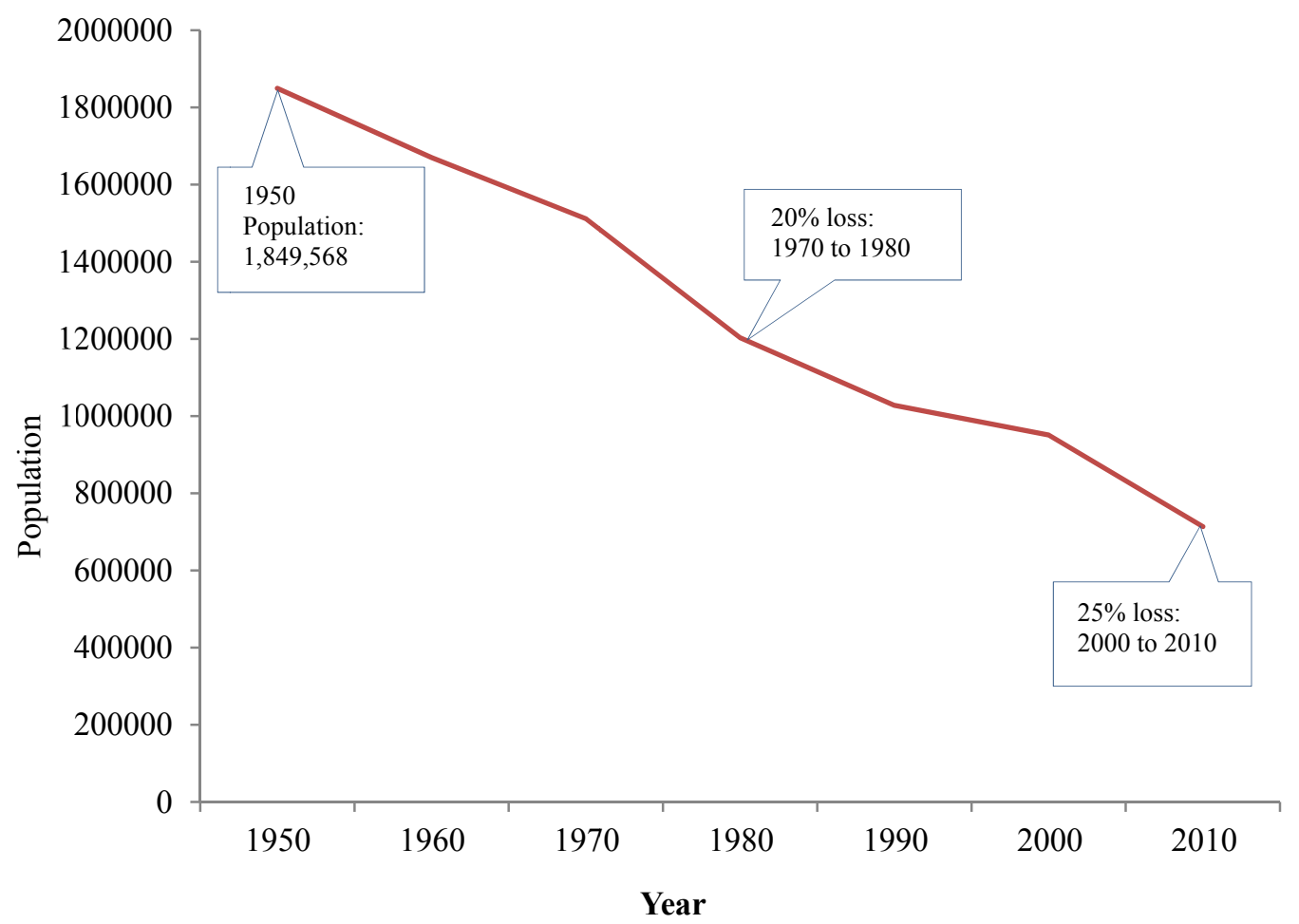

Figure 5. The population decline in Detroit from 1950 to 2010

Source: U.S. Census Bureau.

\section{DETROIT PROPERTY VALUES PLUMMETED IN ‘60S AND '70S}

The exodus of city residents, abandonment of homes and aging housing stock caused a dramatic plunge in assessed property values in Detroit and a corresponding drop in property-tax revenues. They are a core reason behind the city's current financial crisis.

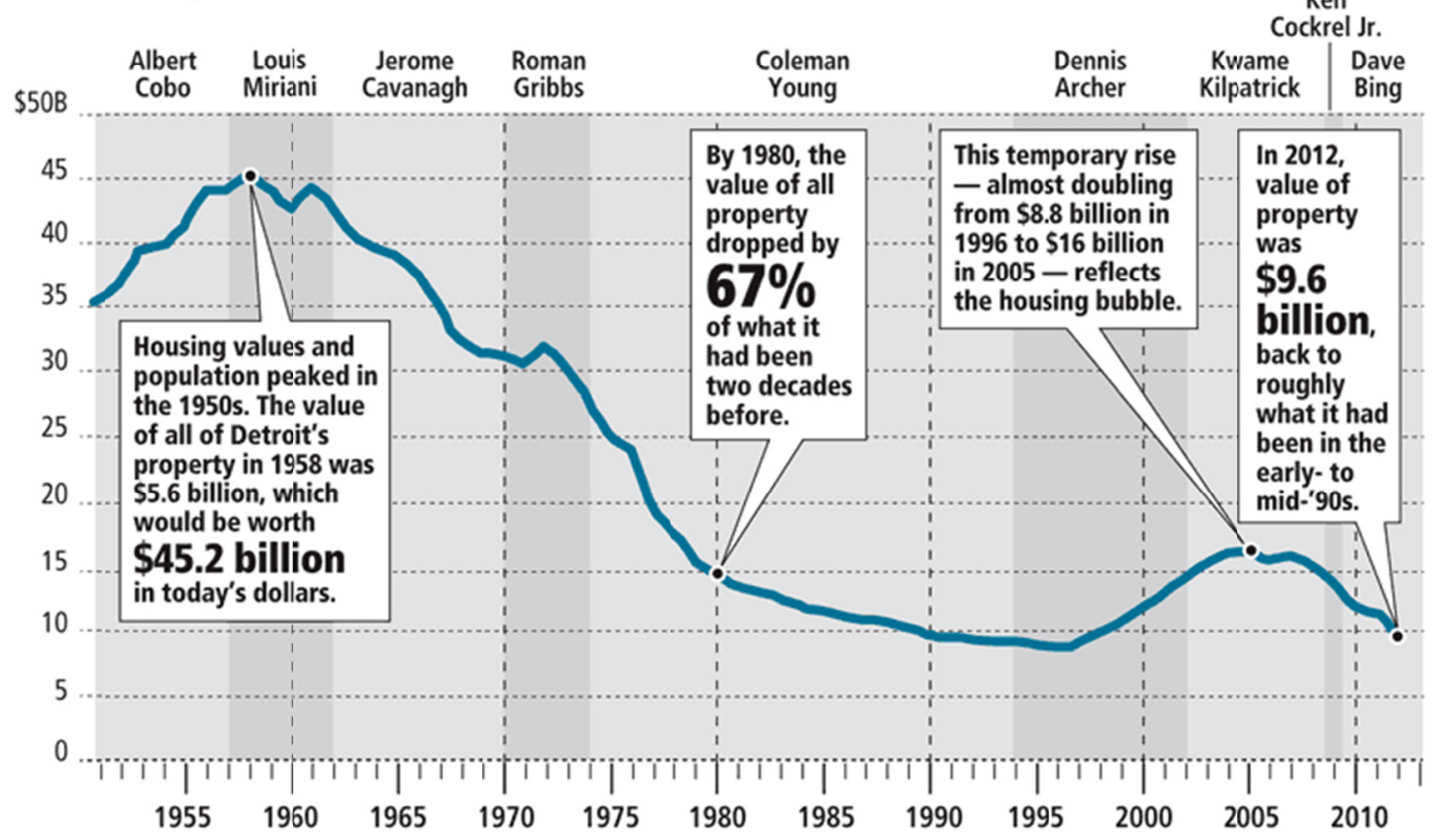

NOTE: All dollar amounts have been adjusted for inflation and are in 2013 dollars.

SOURCE: Detroit's annual financial reports MOSES HARRIS/DETROIT FREE PRESS

Figure 6. The historical trend of property values in Detroit

Note. Reproduced with permission by the Detroit Free Press. 
There are some interactions between urban labor and hosing markets (O'Sullivan, 2012). Since housing is durable: a well-maintained house can last for many decades. As a result, the supply of used housing is relatively inelastic in the downward direction. A decrease in demand-resulting from a decline in population generates a relatively large decrease in price and relatively small decrease in quantity. By the same token, as a city shrinks, locational equilibrium in the regional labor market is restored with a relatively large decrease in the price of housing. Figure 6 shows the historical trend of property values in Detroit. The housing values peaked in the 1950 s when population size was at its maximum. However, by 1980, the value dropped by $67 \%$. Although there was a temporary rise in the housing value in early 2000s largely due to the housing bubble, the value regains its declining path afterwards. As the figure suggests, the property value dropped $78 \%$ by 2012 from its peak.

The significant decline in property value seriously deteriorates the city's tax base since local governments rely primarily on property taxes, while, on the other hand, state governments rely mainly on sales and income taxes for their revenues. In response to the losing tax revenues due to the decline, instead of revisiting its industry investment portfolio diversification strategy, the city of Detroit turned for tax policies. For the first time in 1962, the city instituted a new income tax. Only six years later, in 1968, the rate for residents would double. It was then followed by a $50 \%$ rate increase in 1982 . In the meantime, the city even initiated a $30 \%$ increase in property tax rate to combat the declining tax revenue. These dramatic increases in tax rates make the city a more expensive place to live and hence drive out even more people as well as businesses. Even now, Detroit remains the city in the state of Michigan that has the highest income and property tax rates on its residents. In a further effort to make up the tax revenue shortfalls, the city of Detroit initiated a new utility tax in 1971 and a wagering tax when the casinos began operating in 1999. While these two taxes helped to create more revenues for the city, they are far from enough to compensate for the declining income and property taxes. As Figure 7 shows, the property tax revenues kept on declining over the years. However, the sharpest drop is observed at the year when the city initiated a 30\% increase in the property tax rate. In 1974, the income tax revenues surpass property tax revenues for the first time. Yet, sharing the same fate of property tax, the income tax revenues declined over the years. From 2000 to 2010 alone, the income tax revenue fell 55\%.

\section{EVEN WITH FOUR TAXES, CITY INCOME FALLS TO 60-YEAR LOW}

To compensate for falling property-tax revenue, Detroit imposed new taxes or increased tax rates over the years. Since 1974, the most important tax, in terms of total revenue generated, is the income tax. In 2008, wagering tax revenues from city casinos surpassed property taxes for the first time.

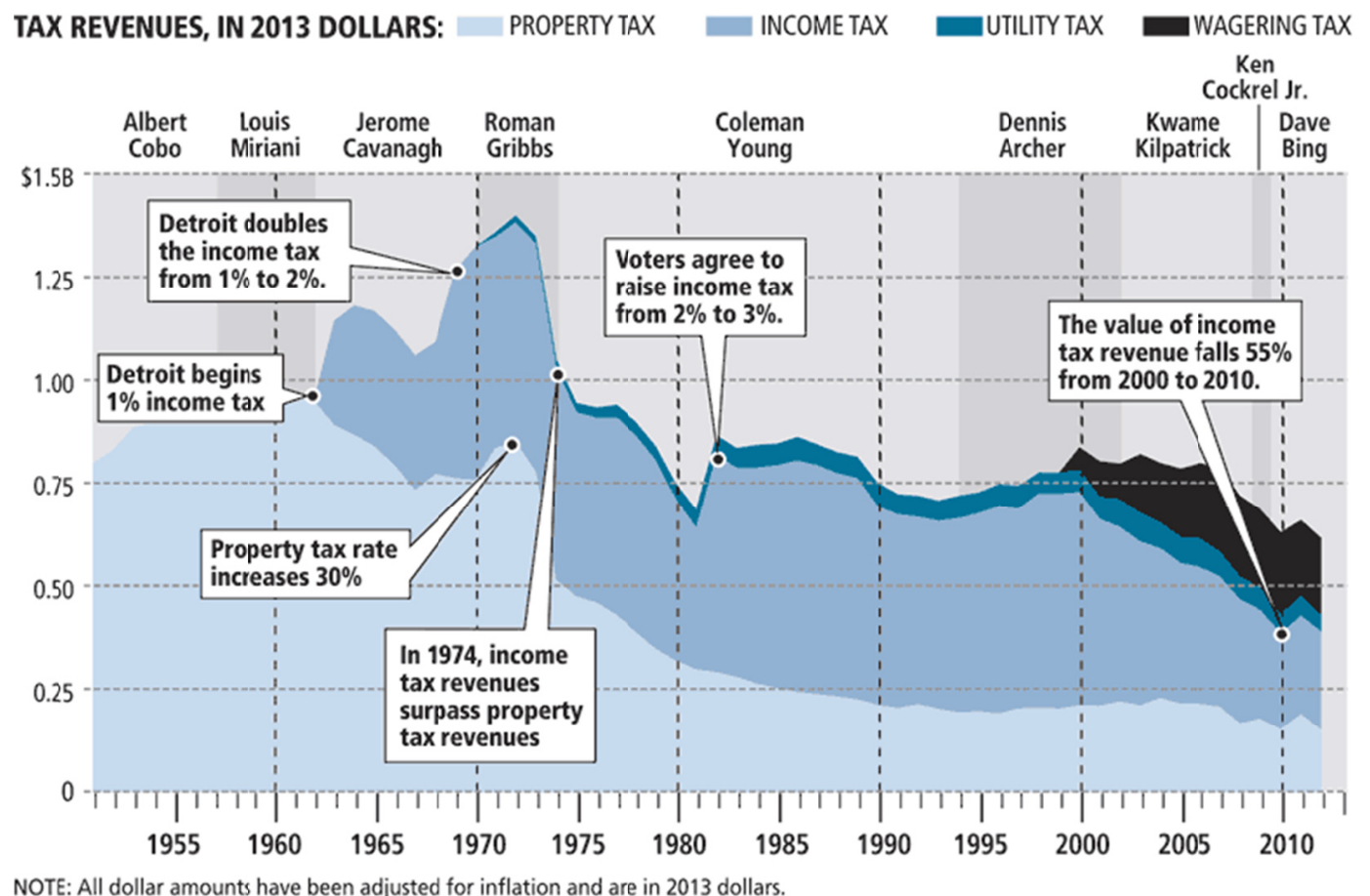

SOURCE: Detroit's annual financial reports

KOFI MYLER/DETROIT FREE PRESS

Figure 7. The composition of Detroit's tax revenues

Note. Reproduced with permission by the Detroit Free Press. 
As the other response to the financial difficulties, the city of Detroit attempted cutting expenses by exercising large scale city employment eliminations along all those years. The cuts in public safety, in particular, lead to an increase in crime (Levitt \& Dubner, 2009) which makes the city not only an expensive and less attractive but also an increasingly dangerous place to live and operate business. As a result, people continue leaving and businesses do not find the city an attractive place to locate. All these finally intensify the city's overall financial difficulties and bankruptcy is only the natural outcome.

\section{Conclusion}

In this study, we offer a financial economist's view on the largest municipal bankruptcy in the U.S. history. While the city of Detroit's financial insolvency has been examined by researchers from various fields and several factors are considered attributable to the event, we believe the center of all issues is merely the city's lack of diversification strategy. This is evidenced by the deteriorating market share of the Big three, the dropping share of auto vehicles \& parts manufacturing employment in Detroit, and the city's long-term trend of declining population. While the auto industry did deliver Detroit a period of prosperity, this over-reliance on one industry inevitably brought financial difficulties on the city as the industry matures along with increased competitions. While the domestic auto makers shrink their production scales and re-locate production facilities, the city of Detroit experienced the harshest impact in the forms of declining job opportunities, dropping property value, and worsening tax base. Instead of strategizing the city's economic development, the city management opted for new taxes, tax increases, and expenditure cuts hoping to cover the revenue shortfall. Yet, these acts only sink the city further to its bankruptcy.

This unfortunate outcome derived from a non-diversifying strategy is well predicted by the Portfolio theory. From the experiences of the cities that successfully rebalanced their industry portfolio such as Denver and Pittsburg, we believe with proper strategy of diversification, the city of Detroit could largely avoid its financial insolvency. The future of Detroit may well still cling to its determination to identify supporting industries and a well-developed economic plan.

This study suggests at least two avenues that warrant future research. First, a detailed comparison and contrast among cities such as Detroit versus Pittsburg can help to further understand the value of the Portfolio theory in a city's economic planning. Second, a systematic analysis on the factors that contribute to a city's economic development is much needed. We believe such an analysis should take a form of multiple equations due to the endogenous natural of some factors. Consider, for instance, population decline and property value. While the two variables are clearly functions of tax rates, they influence each other as well since dropping property value would discourage people buying houses; hence encourage them to move away from the area which in turn leads to further decline in housing value.

\section{References}

Bomey, N., \& Gallagher, J. (2013). How Detroit Went Broke: The Answers may Surprise You and Don't Blame Coleman Young. Detroit Free Press. Retrieved from http://www.freep.com/interactive/article/20130915/NEWS01/130801004/Detroit-Bankruptcy-history-1950debt-pension-revenue

Fainstein, N., \& Fainstein, S. (1983). Regime Strategies, Communal Resistance, and Economic Forces. In S. Fainstein, N. Fainstein, R. C. Hill, \& M. P. Smith (Eds.), Restructuring the City. London: Longman.

Gordon, D. (1978). Capitalist Development and the History of American Cities. In W. Tabb \& L. Sawers (Eds.), Marxism and the Metropolis. New York: Oxford University Press.

Ingrassia, P. (2010). Crash Course: The American Automobile Industry's Road from Glory to Disaster. New York: Random House.

Kleniewski, N., \& Thomas, A. R. (2006). Cities, Changes \& Conflict (4th ed.). Cengage Learning.

Krugman, P. (2013). Detroit, the New Greece. New York Times. Retrieved from http://www.nytimes.com/2013/07/22/opinion/krugman-detroit-the-new-greece.html?_r=0

Levitt, S. D., \& Dubner, S. J. (2009). Freakonomics: A Rogue Economist Explores the Hidden Side of Everything. Harper Perennial.

Markowitz, H. M. (1952). Portfolio Selection. The Journal of Finance, 7(1), 77-91.

Markowitz, H. M. (1959). Portfolio Selection: Efficient Diversification of Investments. New York: John Wiley \& Sons. 
Markusen, A. (1987). Regions: The economic and politics of territories. Totowa, N.J.: Rowman and Littlefield.

McAlinden, S. P., \& Chen, Y. (2012). After the Bailout: Future Prospects for the U.S. Auto Industry. Center for Automotive Research.

O’Sullivan, A. (2012). Urban Economics. McGraw-Hill Irwin.

\section{Notes}

Note 1. For a discussion of other factors, interested readers should refer to Kleniewski and Thomas (2006).

Note 2. When 2006 ended Toyota surged ahead of Chrysler in U.S. sales for the first time. The Big Three were no longer the biggest three in their home market. Automotive News, which had coined the term Big Three eighty years earlier, started calling the companies the "Detroit Three" instead (Ingrassia, 2010).

Note 3. The Bureau of Labor Statistics switched the industrial classification system from the Standard Industry Classification system (SIC) to the North American Industry Classification system (NAIC) in early 1990s. Due to this switch, the detailed industry employment is subject to the definitional differences which leads to the drop of the manufacturing employment as observed in the figure. However, the trend of declining is still persistent.

Note 4. Due to a change in area definitions, the employment figures for the years prior to 1990 are unavailable for the two divisions.

\section{Copyrights}

Copyright for this article is retained by the author(s), with first publication rights granted to the journal.

This is an open-access article distributed under the terms and conditions of the Creative Commons Attribution license (http://creativecommons.org/licenses/by/3.0/). 